\title{
Yiddish in Jewish-American Literature: An Asset to Teaching at German Universities
}

There are many good reasons to teach Jewish-American literature at German universities. An obvious motivation, which hardly applies to the German context alone, is that many novels and short stories of Jewish writers undoubtedly constitute an important part of the canon of American fiction in general. At the same time, this literature falls into the category of minority writing and thus negotiates identities distinct from the American mainstream. Several theoretical concepts of postcolonial studies, 'race,' 'alterity,' and 'hybridity' among them, should be part of a teaching unit on Jewish writing, particularly if it deals with the immigrant experience. The contested idea of the American Melting Pot, popularized by the Jewish-British author Israel Zangwill, may be discussed in conjunction with Jewish-American landmark texts addressing the issue of assimilation. In this essay, I will focus primarily on arguments that are of particular relevance to German higher education: the linguistic particularities of Jewish-American literature by authors of Eastern European descent and the cultural proximity of parts of American Jewry to German students. Apart from my principal aim of facilitating a deeper understanding of Jewish-American literature for them, I also want to bring to mind that Jewish history does not consist of the Holocaust only. Frequently, Jewish history is exclusively equated with the Holocaust, which may preclude an appreciation of existing Jewish life-worlds. I want to counterbalance this tendency by offering students the opportunity to go through complex processes of identification, empathy and understanding.

I have been teaching Jewish-American literature and culture for many years at several universities in Germany and I am now part of the Jewish Studies program at the University of Bamberg, which includes modules on literature, the arts and other aspects of culture. The number of students in this program being modest, most of the participants in the lectures and seminars I teach on this topic are regular students of English and American Studies.

The starting point for my reflections on teaching Jewish literature in this context may sound a bit sobering: Most of the students have very little previous knowledge of Jewish history and culture and - for that matter - languages. Without these insights, clearly, it is hard to understand many of the central concerns, conflicts and stylistic characteristics of Jewish-American fiction.

Our students have certainly learnt a few things about the Jewish faith at school, and one can also rely on reasonable knowledge of the history of anti-Se-

Ә OpenAccess. (C) 2020 Pascal Fischer, published by De Gruyter. (cc) BY-NC-ND This work is licensed under the Creative Commons Attribution-NonCommercial-NoDerivatives 4.0 License. 
mitic persecution in general and the Holocaust in particular. When it comes to Jewish culture beyond that, specific religious tenets, customs, holidays, and aspects of identity - in short - Jewish life, the situation appears to be somewhat disheartening. The German federal state governments put much effort into educating students about the Holocaust, but they are less successful when it comes to educating them about the breadth of Jewish realities - nonwithstanding the fact that many students show a great interest in Jewish topics. To provide an example: As part of my seminar on Jewish-American literature and culture, I ask my students the following question: "What language was spoken by the majority of Jews in Eastern Europe at the end of the nineteenth century?" In a class of more than 20 students, the reaction is generally - silence. Someone may say: "Probably Russian or Polish." "Hebrew" is another answer I have received. If I am very lucky, there may be a student who reluctantly suggests "Yiddish?" When I then tell them that in the Russian census of 1897, almost 98 percent of all Jews living in the Russian Empire claimed Yiddish as their mother tongue (Harshav 1990, 87; Fishman 1991:86), the reaction is surprise - if not incomprehension. Our students do not know that the vast majority of Jews murdered during the Holocaust spoke Yiddish, in fact at least five out of six million (Birnbaum 1988, 3). If I ask the students what kind of language Yiddish is, the reactions are hardly more encouraging. Only few students know that Yiddish is predominantly a Germanic language with Middle High German providing the lion's share of its grammar and lexicon.

The most important Anglophone Jewish-American writers have been of Ashkenazic Eastern European descent and those who wrote fiction in the first decades of the twentieth century regularly depicted processes of integration and assimilation. Since linguistic assimilation is at the center of that, Yiddish and a mixture between Yiddish and English (sometimes referred to as Yinglish) play an eminent role in their novels and short stories. A tutor thus has to provide some information on the cultural and linguistic background of the Jewish immigrants who came to the shores of America around 1900. At the same time, one has to introduce the students to the literary techniques applied by authors to convey something of the character and flavor of their mother tongues, commonly subsumed under the term "literary dialect". (see e.g. Cole 1986; Rothman 1993)

When studying Jewish-American novels with my students, I emphasize the points of similarity between their own culture and Jewish culture without downplaying the differences. This can quite effectively be done by highlighting the connections between German and Yiddish. German-speaking students have the great advantage of understanding most of the Yiddish expressions that appear in the Jewish-American novels I discuss in class. The problems that Jewish liter- 
ary characters face in learning English are similar to the problems of German learners.

At the beginning of my teaching unit on immigrant writing, I thus devote some time to Yiddish. I talk about the history and composition of the language, about regional variants and about the functional diglossia of the mameloshn (mother tongue) Yiddish and the losh koydesh (holy tongue) Hebrew in Eastern Europe (Fishman 1972, 137-140; see Glinert 1987 for a modified view). When I play them a recording of Yiddish, students are confronted with something that sounds familiar and alien at the same time. The last recording I chose was a short contribution from the Forverts Sound Archive about the Yiddish writer Sholem Aleichem (1859-1916). My students enjoy recognizing phrases and frown when they do not. I also show them some written Yiddish in the original with Hebrew letters - and provided them with a schema to transliterate the characters. Since we have talked about Sholem Aleichem anyway, I ask them to read the title of his story די שטאט פון די קליינע מענטשעלעד / The Town of the Small People in the Yiddish original with the help of the alphabet (שלום עליכם 1918 , 9). I may have to help them a little bit, but in the end we come up with: Di Shtot fun die kleyne mentshelekh. Of course, I hope for the epiphanic moment when they suddenly recognize words behind something that looked so utterly strange and opaque to them at the beginning. As the modern German words sound very similar to this, no student has problems understanding the Yiddish title.

Having equipped them with some Hebrew characters, I then present to them Yiddish writing related to the immigrant experience. Yiddish was, after all, the language spoken on the streets of Jewish immigrant neighborhoods in America, of which the Lower East Side of Manhattan was by far the largest. As an example of the identification of many Jewish immigrants with America, I show them the sheet music cover of the song לעבען זאל אמעריקא / Leben zol Amerika. In my explanations of the role of journalism for the integration of Jewish immigrants, I introduce them to the most important Yiddish newspaper, the פَאָרווערטס / Forverts. It certainly helps that my students understand Leben zol Amerika and Forverts as 'Long live America' and 'Forward,' because these are the same words in German.

When reading excerpts of Jewish novels of the late nineteenth and early twentieth centuries with my students, I also emphasize the significance of language in the immigrant experience. The linguistic dimension of that literature cannot only illustrate the hybrid and transcultural nature of immigrant identities (Fischer 2009), it can also open up interesting perspectives for German students.

On the first pages of Elias Tobenkin's 1916 novel Witte Arrives, Masha and her children have just set foot on American soil in the harbor of New York in 1890 and are about to board a train to the Midwest: 
Then came the train with a welcome surprise - a conductor who greeted them in German. There was a difference of centuries between the German which the American conductor spoke and the ghetto Yiddish of Masha Witkowski and her children. Nevertheless she and her children were cheered to the marrow. With a man who spoke German they felt kinship. Masha even took it as a good omen. She put her questions in the most cosmopolitan Yiddish she could summon to her command. (Tobenkin 1916, 2-3)

This is a good opportunity to reflect upon the role of language for our sense of belonging and how the kinship of languages may contribute to a feeling of communality. In view of the Holocaust, reading about the feeling of friendship a Yiddish speaker expresses towards a German speaker may also arouse embarrassment and shame on the part of German students. Around 1900, when antiSemitic writers in Germany increasingly portrayed Jews as the antagonists of the German Volk - Wilhelm Marr and Houston Stewart Chamberlain come to mind - these literary characters take it for granted that Germans and Eastern European Jews are closely related.

Tobenkin's novel can furthermore illustrate that even for Yiddish speakers their language (which some pejoratively called "jargon") had a low prestige in comparison to German (Harshav 1990, 28) and that some speakers tried to elevate their language by bringing it closer to German. In this passage, Germanizing the language primarily fulfils a communicative function - Masha later addresses a policeman with the question "Sprechen Sie Deitsch?" - 'Do you speak German?' (Tobenkin 1916, 7), but in other Jewish-American novels of the period / דייטשמעריש daytshmerish, Yiddish heavily influenced by modern German, is sometimes used by characters who want to flaunt their sophistication and cosmopolitanism. In Abraham Cahan's novella Yekl. A Tale of the New York Ghetto (1896), the narrator points out that the proud immigrant "lady" Mamie has recourse to an "affectedly Germanized" Yiddish (Cahan 1896, 49).

Students may want to speculate why some Jewish-American immigrant novels present bits of transliterated Yiddish - as in the case of Masha's question to the police officer - even though American readers would understand little of it. Most likely, authors like Tobenkin wanted these readers to experience something of the tone of Yiddish. Or maybe, the intended readership was Jewish anyway? In a scene at the immigration office of Ellis Island in Henry Roth's Call it Sleep (1934), the newly arrived Genya asks her husband Albert, who has already spent some time in America, shortly after their reunion:

"Gehen vir voinen du? In Nev York?”

“Nein. Bronzeville. Ich hud dir schoin geschriben.” (Roth 1934, 12) 
This may sound a bit strange to them, but most German students will be able to figure out the meaning of these words: ${ }^{1}$ 'Are we going to live / dwell in New York? No. Brownsville. I have already written you.'

In the following example from Cahan's Yekl the recently arrived immigrant woman Gitl does not speak English yet. While most of her Yiddish is rendered as perfect English, the novel also provides a line of transliterated Yiddish, but a Yiddish that has been influenced by English. Gitl's husband Yekl has just criticized his wife for still using the Yiddish word "fentzter" instead of the word "window", which has entered the Yiddish lexicon in America. Gitl apologizes and promptly inserts the English word "window": "Es is of'n veenda mein ich.” (Cahan 1896, 41) - 'It is on the window, I mean'. My German students, of course, recognize the German Fenster behind the unusual spelling of the Yiddish word.

Jewish-American novels of that period repeatedly illustrate the problems immigrants face in learning English. Roth's Call it Sleep, a novel that focuses on the experience of a little boy of six to eight years, presents us with a scene in the Cheder, the Jewish primary school. While the pupils are required to speak Yiddish with the Rabbi and have to learn Hebrew in their lessons, they speak an English immigrant dialect among themselves and proudly show off their vocabulary. But when a kid substitutes the Yiddish word "blitz" for the English word "lightening," he is taunted by his classmate:

"I seen a blitz just w'en I commed in."

"A blitz, yuh dope!"

"So hoddy you say blitz wise guy?"

“A lighten’, yuh dope. A blitz! Kent’cha tuck Englitch? Ha! Ha!” (Roth 1934, 309)

The shaky pronunciation of English and the many grammatical mistakes are less important than the use of the right vocabulary. The little boy is still later derided as a "greenhorn" for his use of "blitz".

It should be explained to the students that in the case of such a great author as Henry Roth, the play with languages is more than an attempt at realism, as Hana Wirth-Nesher superbly explains in her reading of the novel. There is, for instance, a very subtle form of humor in the interlinguistic pun contained in Englitch (Wirth-Nesher 2006, 3; 78) The word appears to be a composite of English and the Yiddish word גליטש / glitsh 'slip', which German students will also recognize from the verb glitschig 'slippery' in their language. Remarkably, the Yiddish word has entered the English lexicon as glitch - 'malfunction'. Wirth-Nesher also

1 The correct Yiddish form should be "ich hob" איך האָב rather than "ich hud". 
points to the subversive tendency of this use of language. The development of the word glitch may also be a good opportunity to recapitulate the students' insights into contact linguistics.

Yiddish expressions still play a role in post-war Jewish-American literature. In Bernard Malamud's The Assistant (1957), the Jewish character Breitbart answers the question "How is it going?" with "Schwer." (Malamud 1957, 245) The word means 'hard' or 'difficult' in Yiddish as well as in German. Some students realize that Breitbart, who speaks English fluently, could have used an English expression, but prefers the Yiddish word, as it more adequately seems to encapsulate his notion of Jewish suffering. After the Holocaust, Yiddish is not the language of the "greenhorn" in the first place, but the language of the victims.

In most of the texts I discuss in class, the Yiddish words facilitate identification with the Jewish characters. The shared heritage of Yiddish and German may lead to a feeling of communality and thus enhance understanding. At the same time, I do not want to create the impression that the relationship between Eastern European speakers of Yiddish and central European speakers of German has ever been easy. Jewish-American novels by authors of Eastern European descent regularly address the conflicts between their own history of immigration and the one experienced by German Jews, who had come to America before them, chiefly in the middle decades of the nineteenth century, and had achieved some prosperity there. These conflicts have been an important part of the Jewish-American narrative ever since.

Talking about the success stories of German Jewry in America is not hard in Bamberg, as many prominent German Jews emigrated from that region - Franconia - to America (Wilhelm 2012). In order to render this part of Jewish-American history tangible, I try to anchor the individual life stories of some noteworthy immigrants into the local geography my students are familiar with. I talk about the Gebrüder Lehmann from Rimpar near Würzburg, who called themselves the "Lehman Brothers" in America (Flade 1999). I mention Mark Goldmann from Trappstadt and his son-in-law Samuel Sachs, the son of his friend Joseph Sachs, whom Goldmann had met in the religious school in Würzburg (Caplan 2012). Of course, students are familiar with the investment bank Goldman Sachs. I furthermore point out that the upscale department store chain Bloomingdale's was founded by immigrants from Gunzenhausen (Barkai 1994, 82). Most of my students are aware of the fact that Löb Strauß, or Levi Strauss, the founder of Levi's Jeans, was born in Buttenheim, just fifteen minutes south of Bamberg. In the house where he was born, there is now a small museum that brings to life his Jewish-Franconian heritage, the history of his emigration and his career in America. To set a counterpoint to these business people, I also mention that important American rabbis had come from Franconia, among them 
Abraham Reiss/Rice, who was born in Gochsheim and became the first rabbi in the United States; Leo Merzbacher from Fürth, first rabbi of Temple Emanu-El in New York City; and Kaufmann Kohler, the famous reform rabbi of Cincinnati, who was born in Fürth as well. I have the impression that some of my Franconian students are not only surprised to learn about this part of the history of their native region, but also take pride in it.

German Jews are generally viewed with awe by the Yiddish-speaking immigrants in Jewish-American fiction of the early 1900s, but they also excite their envy or even incur their wrath. Philip, a Yiddish-speaking character in Samuel Ornitz' Allrightniks Row “Haunch, Paunch and Jowl” (1923) primarily sees German Jews as exploiters of Eastern European immigrants and gets all worked up about "these damned nice, superior people, the German Jews: so good, so respectable, so proud: with their vaunted charities and rich temples which make you worms grovel before them. They are the ones who have been grinding you." (Ornitz 1923, 102) Similarly, in Abraham Cahan's The Rise of David Levinsky (1917) the German Jew Jeff Manheimer is presented as a relentless boss in the garment industry who looks down upon his coreligionists from Russia: "Altogether he treated us as an inferior race, often lecturing us upon our lack of manners.” (Cahan 1917, 187)

I find it particularly productive to encourage students to assume different perspectives in these intra-Jewish confrontations. On the one hand, they may find it easier to relate to the culturally closer German Jews, on the other, these narratives are designed to channel sympathy to the Yiddish-speaking victims of exploitation. This leads to interesting processes of reflection, loyalty and empathy, which may, hopefully, contribute to my overall learning objective, namely to arrive at a better understanding of the complexity of Jewish existence. If I am lucky, my students more fully appreciate Jews in their multifaceted existence involved in conflicts, struggling to get by in the world; some successful, some not; some happy, some sad; some hopeful, some frightened - just like the rest of humankind.

\section{Bibliography}

Barkai, Avraham. Branching Out. German-Jewish Immigration to the United States, 1820-1914. New York: Holmes \& Meier, 1994.

Birnbaum, Salomo A. Grammatik der Jiddischen Sprache. Mit einem Wörterbuch und Lesestücken. Hamburg: Helmut Buske, ${ }^{5} 1988$.

Caplan, Sheri J. "Marcus Goldman”. Immigrant Entrepreneurship: German-American Business Biographies, 1720 to the Present, vol. 2. Ed. William J. Hausman. German Historical Institute. https://www.immigrantentrepreneurship.org/entry.php?rec=100 
Cahan, Abraham. Yekl and The Imported Bridegroom. And Other Stories of Yiddish New York. New York: Dover Publications, 1970 [11896 Yekl. A Tale of the New York Ghetto].

Cahan, Abraham. The Rise of David Levinsky. With an Introduction and Notes by Jules Chametzky. New York: Penguin Books, 1993 [11917].

Cole, Roger W. "Literary Representations of Dialect: A Theoretical Approach to the Artistic Problem." The USF Language Quarterly 24.3+4 (1986): 3-8.

Fischer, Pascal. "Linguistic Dimensions of Jewish-American Literature.” Transcultural English Studies: Theories, Fictions, Realities. Ed. Frank Schulze-Engler; Sissy Helff. Amsterdam/New York: Rodopi, 2009. 169-185.

Fishman, Joshua. Language in Sociocultural Change. Stanford: Stanford University Press, 1972.

Fishman, Joshua. Yiddish: Turning to Life. Amsterdam: Benjamins, 1991.

Flade, Roland. The Lehmans: From Rimpar to the New World. A Family History. Würzburg: Königshausen u. Neumann, 1999 [11996].

Glinert, Lewis. "Hebrew-Yiddish Diglossia: Type and Stereotype Implications of the Language of Ganzfried's Kitzur." International Journal of the Sociology of Language 67 (1987): $39-56$.

Harshav, Benjamin. The Meaning of Yiddish. Berkeley: University of California Press, 1990.

Malamud, Bernard. The Assistant. New York: Farrar, Straus \& Company, 1963 [11957].

Ornitz, Samuel. Allrightniks Row "Haunch, Paunch and Jowl": The Making of a Professional Jew, New York: Markus Wiener Publishing, 1986 [1923].

Roth, Henry. Call it Sleep. New York: Cooper Square Publishers, 1970 [11934].

Rothman, David J. "Notes toward a Theory of Literary Dialect." Hellas. A Journal of Poetry and the Humanities 4.2 (1993):123-35.

Ale Verk fun Sholem Alechem, Bd. 3: קליינע מענטשעלעך מיט קליינע משלעך השגות. New York, 1918. 9-17.

Tobenkin, Elias. Witte Arrives. New York: The Gregg Press, 1968 [11916].

Wilhelm, Cornelia. "Die Emigration der Fränkischen Juden im 19. Jahrhundert nach Amerika." Die Juden in Franken. Ed. Michael Brenner; Daniela F. Eisenstein. München: Oldenbourg, 2012. 169-180.

Wirth-Nesher, Hana. Call it English: The Languages of Jewish American Literature. Princeton: Princeton University Press, 2006. 